Vol. 6, No.3, September 2020, 195-203

\title{
KUALITAS PRODUK TERHADAP KEPUASAN KONSUMEN MENGGUNAKAN SEPATU FUTSAL MEREK SPECS DI PALU
}

\author{
Anugrah Moh Nur \\ Syamsul Bahri \\ Nirwan
}

Program Studi S1 Jurusan Manajemen Fakultas Ekonomi dan Bisnis, Universitas Tadulako

Email : anugrahmohnur17@gmail.com;syamsulbahridgparani@gmail.com;nirwan.fe.untad@gmail.com

\begin{abstract}
This research is a combination of descriptive and causal research. This research was conducted on those who is using Specs shoes in Palu City and the number of samples set was 90 respondents, then the samples were taken based on the purposive sampling method. Data collection is done by using questionnaires. The method of data analysis is done by multiple linear regression methods using the help of SPSS software version 16. Data that has fulfilled the research instrument test and the classic assumption test are processed so as to produce the regression equation as follows: The results showed that the eight product quality variables, namely shape, features, performance, suitability, durability, reliability, ease of repair, and style had significant results. So it can be concluded that the shape, features, performance, suitability, durability, reliability, ease of repair, and style can have a positive effect on consumer satisfaction using Specs shoes in the City of Palu.
\end{abstract}

Keywords: Consumer Satisfaction, Product Quality.

\begin{abstract}
Abstrak
Jenis penelitian ini gabungan dari penelitian deskriptif dan kausal. Penelitian dilakukan kepada yang menggunakan sepatu futsal merek Specs di Kota Palu dan jumlah sampel sebanyak 90 responden, kemudian sampel tersebut diambil berdasarkan metode purposive sampling. Pengumpulan data dilakukan dengan cara menyebar kuesioner. Metode analisis data dilakukan dengan metode regresi linear berganda menggunakan bantuan software SPSS versi 16. Data yang telah memenuhi uji instrumen penelitian dan uji asumsi klasik diolah kemudian menghasilkan persamaan regresi sebagai berikut: Hasil dari penelitian menunjukan kedelapan variabel kualitas produk yaitu bentuk, fitur, kinerja, kesesuaian, ketahanan, kehandalan, kemudahan perbaikan, gaya memiliki hasil yang signifikan. Sehingga bisa disimpulkan bahwa bentuk, fitur, kinerja, kesesuaian, ketahanan, kehandalan, kemudahan perbaikan, dan gaya dapat berpengaruh positif terhadap kepuasan konsumen menggunakan sepatu futsal merek Specs di Kota Palu.
\end{abstract}

Kata kunci: Kepuasan Konsumen, Kualitas Produk.

\section{PENDAHULUAN}

Keinginan setiap perusahaan menerapkan strategi yang berorientasi pada kepuasan konsumen, nampak dari berbagai usaha maupun kegiatan yang dilakukan melalui banyaknya produk yang diluncurkan dengan berbagai merek dan promosi. Orientasi pelanggan merupakan faktor kunci keberhasilan dunia pemasaran moderen. Setiap organisasi, baik yang berorientasi pada laba maupun non laba, wajib menggunakan sudut pandang konsumen merencanakan dan mengorganisasikan aktivitas-aktivitas pemasarannya. Perusahaan harus memiliki keunggulan yang dapat membedakan produk perusahaannya dengan produk perusahaan lain. Hal inilah yang disebut sebagai Kompetitive advantage atau keunggulan bersaing bagi perusahaan tersebut sehingga perusahaan dapat mempertahankan posisi atau meningkatkan pendapatannya dibandingkan dengan perusahaan lain yang sejenis.

Konsep kualitas produk ini digunakan oleh perusahaan untuk menimbulkan kepuasan konsumen atas produk dan jasa yang ditawarkan pihak perusahaan serta mengukur seberapa besar pengaruh dari kualitas produk terhadap kepuasan konsumen menggunakan produk. Menyadari akan pentingnya pelanggan untuk menentukan kesuksesan suatu usaha, maka dalam hal ini perusahaan berusaha keras bersaing dalam menarik setiap konsumen untuk menggunakan produk yang ditawarkan.

Konsep yang digunakan untuk menciptakan competitive advantage oleh suatu perusahaan salah satunya adalah kualitas produk. Kotler dan Keller (2016:156) "product quality is the overall features 
and characteristics of a product that suits its ability to meet its implied needs". kualitas produk adalah semua/keseluruhan fitur dan karakteristik produk yang sesuai dengan kemampuannya untuk memenuhi kebutuhan tersirat. Kualitas produk, menurut Kotler dan Keller (2016:393) ada delapan dimensi, yaitu: form (Bentuk), features (Fitur), performance (kinerja), conformance (Kesesuaian), durability (Daya tahan), reliability (Keandalan), repairabillity (kemudahan perbaikan), style (Gaya).

Olahraga futsal salah satu olahraga yang diminati masyarakat Kota Palu dari kalangan anak-anak hingga kalangan dewasa, Untuk menunjang permainan di lapangan dibutuhkan peralatan dengan kualitas yang baik. Sepatu futsal menjadi faktor utama yang paling diperhatikan kualitasnya untuk menunjang permainan di atas lapangan. Sepatu futsal merek Specs ialah sepatu futsal buatan Indonesia yang menggunakan Phylon sebagai peredam benturan dan dilengkapi dengan Flexiarc serta teknologi Vertecs yang membantu bentuk sepatu untuk mengikuti kaki pemain sehingga memberikan fit dan grip yang maksimal. Sepatu futsal merek Specs selalu berusaha meningkatakan kualitas produknya untuk menciptakan kepuasan konsumen dan dapat bersaing dengan sepatu futsal merek Adidas dan sepatu futsal merek Nike buatan luar negeri yang ada di Kota Palu.

Untuk penerapan kualitas produk pada sepatu futsal merek Specs dapat dilihat mulai dari bentuk, sepatu futsal merek Specs memiliki bentuk dengan desain yang moderen, adanya penambah pelindung tulang engkel menambah bentuk sepatu futsal merek specs menjadi lebih indah.

Fitur, sepatu futsal merek specs memiliki fitur Vertecs yaitu teknologi Outsole yang dapat melindungi kaki untuk menghindari cedera dan fitur Flexiarc yaitu teknologi yang dapat memungkinkan melakukan pivot dengan cepat. Kinerja, sepatu futsal merek specs bisa memberikan kemudahan terhadap penggunanya untuk melangkah pada saat dipakai dan berakselerasi dengan maksimal di lapangan. Kesesuaian, sepatu futsal merek Specs menawarkan harga sesuai dengan semua spesifikasi yang telah dijanjikan dan memiliki tingkat keamanan sama dengan sepatu futsal lainnya.

berdasarkan wawancara yang telah dilakukan dengan para pemakai sepatu futsal merek Specs di lapangan futsal pipit, yang mengatakan teknologi phylon bisa peredam benturan yang dilengkapi dengan flexiarc serta teknologi vertecs yang membantu bentuk sepatu untuk mengikuti kaki pemain sehingga memberikan fit dan grip yang maksimal. kehandalan, sepatu futsal merek Specs tidak mudah rusak dalam jangka waktu pendek. Bisa digunakan dalam kondisi apapun lapangan yang ada dan tidak mudah mengelupas ketika terjadi gesekan pada saat digunakan menendang bola.

Kemudahan perbaikan, sepatu futsal merek Specs tidak membutuhkan biaya yang banyak untuk melakukan perbaikan ketika terjadi kerusakan. tersedianya jasa perbaikan, semua jenis sepatu termasuk sepatu futsal dapat membantu semua pengguna sepatu futsal merek specs mengurangi biaya uang dan waktu. Variabel yang terakhir adalah gaya, sepatu futsal merek Specs memiliki keindahan dengan kombinasi warna yang menarik.

Memiliki tampilan yang sulit untuk ditiru dan logopada sepatu futsal merek Specs yang memiliki arti sujud kemenangan para atlet menambah keindahan pada sepatu futsal merek Specs. Variabel yang terakhir adalah gaya, sepatu futsal merek Specs memiliki keindahan dengan kombinasi warna yang menarik. Memiliki tampilan yang sulit untuk ditiru dan logo pada sepatu futsal merek Specs yang memiliki arti sujud kemenangan para atlet menambah keindahan pada sepatu futsal merek Specs. Berdasarkan hasil wawamcara yang dilakukan oleh peneliti dengan melakukan wawancara mendalam kepada beberapa pengguna sepatu futsal merek Specs di Kota Palu. dan sepatu futsal merek Specs ini hampir mirip dengan kualitas buatan luar negeri seperti Adidas dan Nike.

\section{KAJIAN LITERATUR DAN KERANGKA PEMIKIRAN}

Konsep paling penting yang melandasi pemasaran adalah keinginan manusia. Seiring dengan perkembangan jaman, kebutuhan berkembang menjadi suatu keinginan mengkonsumsi sautu produk dengan ciri khas tertentu. Munculnya keinginan akan menimbulkan permintaan spesifik terhadap suatu jenis produk. Apabila konsumen percaya akan nilai dan kepuasan yang akan didapat, konsumen akan 
melakukan pertukaran dan transaksi jual beli barang dan jasa. Hal ini yang mendasari terjadinya pasar. Pemasaran merupakan salah satu ilmu yang sangat penting untuk kelangsungan kemajuan suatu perusahaan. Barang-barang yang dihasilkan perusahaan bisa sampai hingga ke tangan konsumen itupun tidak terlepas dari pengelolaan pemasaran yang baik. Berbagai macam pengertian pemasaran yang dikemukakan oleh para ahli, namun pada intinya pendapat mereka itu hampir sama antara satu dengan lainnya. Menurut Kotler dan Keller (2016) "marketing is about identifying and meeting human and social need". pemasaran adalah tentang mengidentifikasi dan memenuhi kebutuhan manusia dan social. Abdullah \& Tantri (2012:14 ) mengatakan bahwa : "pemasaran adalah suatu sistem total dari kegiatan bisnis yang dirancang untuk merencanakan, menentukan harga, mempromosikan dan mendistribusikan barang-barang yang dapat memuaskan keinginan dan jasa baik kepada para konsumen saat ini maupun konsumen konseptual.

Kepuasan konsumen dapat ditemukan setelah pelanggan membandingkan pangalaman mereka dalam melakukan pembelian barang/jasa dari penjual atau penyedia barang/jasa dengan harapan dari pembeli itu sendiri. Harapan tersebut terbentuk melalui pengalaman pertama mereka dalam membeli suatu barang/jasa, komentar teman dan kenalan, serta janji dan informasi pemasar dan pesaingnya. Pemasar yang ingin unggul dalam persaingan tentu harus memperhatikan harapan konsumen serta kepuasan konsumennya.

Kotler dan Keller (2016:153) "satisfaction is a person's feelings of pleasure or disappointment that result from comparing a product or service's perceived performance (or outcome) to expectations. If the performance or experience falls short of expectations, the customer is dissatisfied. If it matches expectations, the customer is satisfied. If it exceeds expectations, the customer is highly satisfied or delighted".

Kepuasan adalah perasaan bahagia atau kecewa seseorang yang muncul dari membandingkan suatu produk atau kinerja yang dirasakan terhadap harapan. Jika kinerja atau pengalaman tidak sama dengan harapan, pelanggan tidak puas. Jika sesuai dengan harapan, pelanggan merasa puas. Jika melebihi harapan, pelanggan sangat puas atau senang. Perkembangan tuntutan dalam dunia usaha, dimana perusahaan harus mampu membuat konsumen menjadi puas dengan cara menawarkan produk yang berkualitas sesuai dengan permintaan konsumen.

Kualitas produk merupakan hal penting dalam menentukan pilihan produk oleh konsumen. Produk yang ditawarkan harus benar-benar teruji dengan baik mengenai kualitasnya karena yang diutamakan konsumen adalah kualitas produk itu sendiri. Hal ini karena konsumen lebih menyukai produk yang mempunyai kualitas lebih baik bila dibandingkan dengan produk lain sejenis yang dapat memenuhi kebutuhan dan keinginannya.

Menurut Kotler dan Keller (2016:156) "product quality is the overall features and characteristics of a product that suits its ability to meet its implied needs". kualitas produk adalah semua fitur dan karakteristik dari produk yang sesuai dengan kemampuannya untuk memberikan kebutuhan tersirat. Untuk membuktikan kualitas produk menurut Kotler dan Keller (2016:393) kualitas produk dapat dimasukkan ke dalam delapan dimensi, yaitu: form (Bentuk), features (Fitur), performance (kinerja), conformance (Kesesuaian), durability (Daya Tahan), reliability (Keandalan), repairabillity (kemudahan perbaikan), style (Gaya).

\section{METODE PENELITIAN}

Jenis penelitian ini adalah deskriptif kausal. Riset kausal ini sangat searah untuk tujuan seperti memahami variabel yang menjadi penyebab (variabel independen) dan variabel yang menjadi akibat (variabel dependen) dari suatu fenomena dan menentukan karakteristik pengaruh antara variabel kausal dan dampak yang diprediksi. penelitian ini secara langsung melakukan penelitian pada objek penelitian, dengan tujuan untuk melihat variabel yang berpengaruh terhadap kepuasan konsumen menggunakan sepatu futsal merek Specs di Kota Palu, artinya peneliti akan mencoba pengaruh 
variabel independen terhadap variabel dependen dengan maksud menguji hipotesis melalui penelitian statistik.

Penelitian ini mengambil objek pada pengguna sepatu futsal merek Specs di Kota Palu. Dengan judul penelitian "Pengaruh Kualitas Produk Terhadap Kepuasan Konsumen Menggunakan Sepatu Futsal Merek Specs di Kota Palu". Dimensi Kualitas Produk antara lain: Bentuk, Fitur, Kinerja, Kesesuaian, Ketahanan, Kehandalan, Kemudahan perbaikan, Gaya, dimana dimensi Kualitas Produk ialah variabel yang mempengaruhi Kepuasan Konsumen Menggunakan Sepatu Futsal Merek Specs di Kota Palu.

Untuk menentukan sampel peneliti merujuk pada pendapat Roscoe (dalam Sugiyono 2016:165) bila dalam penelitian akan melakukan analisis dengan multivariate (kolerasi atau regresi ganda misalnya), maka jumlah anggota sampel minimal 10 kali dari jumlah variabel yang ada. Berdasarkan teori tersebut, maka penentuan besar sampel adalah sebagai berikut: Besar sampel $=10(8+1)=10(9)=$ 90

Teknik penarikan sampel dalam penelitian ini adalah purposive sampling dengan kriteria responden yang dijadikan sampel pada penelitian ini adalah sebagai berikut:

1. Bersedia mengisi kuisioner yang diberikan.

2. Konsmumen yang menggunakan sepatu futsal merek Specs.

3. Berusia dari 16 tahun.

Uji validitas menunjukan sejauh mana sudah kehandalan sebuah alat ukur dalam mengukur apa yang akan diukur. uji validitas digunakan untuk mengetahui sejauh mana tingkat ketepatan dari indikator pertanyaan yang diaujukan dalam sebuah kuesioner penelitian. Untuk mengetahui apakah instrument tersebut valid, maka digunakan uji validitas dengan menggunakan analisis butir, dengan Teknik kolerasi. Pendapat Masrun (dalam Sugiyono 2016:218) menyatakan "item yang mempunyai korelasi positif dengan kriterium (skor total) serta korelasi yang tinggi. Syarat minimum untuk memenuhi syarat adalah $0,3(r \geq 0,3)$ " maka instrument tersebut dinyatakan valid.

Uji reliabilitas menggambarkan sejauh mana alat ukur di sebuah penelitian dapat diandalkan. Bila sebuah alat ukur dipakai dua kali untuk mengukur gejala yang mirip dan hasil dari pengukuran tersebut relatif konsisten, maka alat tersebut dinyatakan reliabel. Pengujian reliabilitas instrument penelitian secara internal dapat dilakukan dengan menggunakan Teknik yang memisah item instrument menjadi dua kelompok lalu kemudian ditotal. Menurut sugiyono (2016:220) suatu instrument dinyatakan reliabel bila koefisien reliabilitas minimal $0,6(\alpha \geq 0,6)$.

Uji multikolinieritas dimaksudkan untuk mengetahui apakah diantara variabel independent tidak saling berkolerasi atau tidak terhadap hubungan yang signifikan antara variabel. Adakalanya korelasi yang tinggi diantara beberapa variabel independent menyebabkan kita tidak dapat untuk mengisolasi pengaruh individual dari variabel bebas terhadap variabel terkait. Bila antara variabel bebas terdapat korelasi secara sempurna atau mendekati sempurna, maka model analisis regresi tidak dapat digunakan. Suatu variabel menunjukan gejala multikolinieritas dapat dilihat dari nilai VIF (variance Inflation factor) yang tinggi pada variabel-variabel bebas suatu model regresi. Jika nilai VIF lebih besar dari 10 menunjukan adanya gejala multikolinieritas dalam model regresi dan jika nilai VIF lebih kecil dari 10 menunjuka tidak adanya gejala multikolinieritas dalam model regresi.

Uji heteroskedasitisitas bertujuan untuk mengetahui apakah dalam model regresi terjadi ketidaksamaan varian dari suatu residual pengamatan ke pengamatan yang lain. Salah satu cara untuk mendekati heteroskedasitisitas adalah dengan melihat grafik scatter plot antara nilai prediksi variabel terikat (ZPRED) dengan residualnya (SRESID). Jika ada titik-titik membentuk pola tertentu teratur seperti bergelombang, melebar, kemudian menyempit maka telah terjadi heteroskedasitisitas. Jika titik-titik menyebar di atas dan di bawah $0 \mathrm{Y}$ tanpa membentuk pola tertentu maka tidak terjadi heteroskedasitisitas. Ghozali (2005:105). 
Vol. 6, No.3, September 2020, 195-203

Normalitas bertujuan menguji apakah dalam sebuah model regresi, variabel dependen (terikat), variabel independent (bebas) atau keduanya mempunyai distribusinormal ataukah tidak. Model regresi yang bagus ialah distribusi data normal atau mendekati normal. Deteksi normalitas dilakukan dengan cara melihat penyebaran data (titik) pada sumbu diagonal grafik. Dasar pengambilan keputusan adalah:

1. Jika data tersebut tersebar disekitar garis diagonal dan mengikuti garis diagonal, maka model regresi memenuhi asumsi normalitas.

2. Jika data menyebar jauh dari garis diagonal atau tidak mengikuti arah garis diagonal, maka model regresi tidak memenuhi asumsi normalitas.

Untuk menjawab permasalahan dan menguji hipotesis dalam penelitian ini digunakan analisis kualitatif dengan memaparkan hasil-hasil penelitian di lapangan secara deskriptif dan analisis kuantitatif dengan menggunakan angka-angka statistik melalui penggunaan alat analisis statistik parametrik Regresi Linear Berganda (Multiple Regression Linear) dapat digambarkan sebagai berikut. Sugiyono (2013:227) :

Dimana:

Y $\quad=$ Variabel Dependen

a $\quad=$ Konstanta

b1-bn = Koefisien Regresi

$\mathrm{X} 1-\mathrm{Xn}=$ Variabel Independen

Bila formulasi matematis Regresi Linear Berganda tersebut diaplikasikan dalam penelitian ini, maka akan diperoleh bentuk persamaan sebagai berikut:

Dimana:

$\mathrm{Y} \quad=$ Kepuasan konsumen menggunakan sepatu futsal Specs

a $\quad=$ Konstanta/intercept

b1-b8 = Koefesien yang diukur

$\mathrm{X} 1=$ Bentuk

$\mathrm{X} 2=$ Fitur

$\mathrm{X} 3=$ Kinerja

$\mathrm{X} 4=$ Kesesuaian

$\mathrm{X} 5=$ Ketahanan

$\mathrm{X} 6=$ Kehandalan

$\mathrm{X} 7=$ Kemudahan Perbaikan

$\mathrm{X} 8=$ Gaya 
Tabel 1. Rekapitulasi Hasil Uji Regresi Linear Berganda Coefficients $^{\mathbf{a}}$

\begin{tabular}{|c|c|c|c|c|c|}
\hline & \multirow{2}{*}{ Model } & \multicolumn{2}{|c|}{ Unstandardized Coefficients } & \multirow{2}{*}{$\begin{array}{c}\begin{array}{c}\text { Standardizerd } \\
\text { Coefficients }\end{array} \\
\text { Beta }\end{array}$} & \multirow{2}{*}{ Sig.t } \\
\hline & & $\bar{B}$ & Std. Error & & \\
\hline \multirow[t]{10}{*}{1} & (Constant) & .578 & .740 & & .010 \\
\hline & Bentuk (X1) & .396 & .161 & .311 & .016 \\
\hline & Fitur (X2) & .046 & .060 & .265 & .046 \\
\hline & Kinerja (X3) & .185 & .080 & 281 & .007 \\
\hline & Kesesuaian $(\mathrm{X} 4)$ & .017 & .164 & .352 & .000 \\
\hline & Ketahanan (X5) & .138 & .064 & .273 & .034 \\
\hline & Kehandalan (X6) & .066 & .119 & .321 & .003 \\
\hline & Kemudahan & & & & \\
\hline & Perbaikan (X7) & .052 & .103 & .308 & .004 \\
\hline & Gaya (X8) & .221 & .081 & .297 & .008 \\
\hline \multicolumn{2}{|l|}{$\mathrm{R}$} & $=0,601$ & & $\operatorname{sig} \mathrm{F}$ & $=0,000$ \\
\hline \multicolumn{2}{|c|}{$\mathrm{R}$ square } & $=0,562$ & & & \\
\hline \multicolumn{2}{|c|}{ Adjusted R Square } & $=0,599$ & & & \\
\hline
\end{tabular}

\section{Sumber: Data Primer Diolah Kembali}

Dari hasil uji regresi yang tertera pada tabel 2 di atas, dapat diketahui bahwa persamaan regresi yang didapatkan adalah: $\mathrm{Y}=\mathrm{a}+\mathrm{b} 1 \mathrm{X} 1+\mathrm{b} 2 \mathrm{X} 2+\mathrm{b} 3 \mathrm{X} 3+\mathrm{b} 4 \mathrm{X} 4+\mathrm{b} 5 \mathrm{X} 5+\mathrm{b} 6 \mathrm{X} 6+\mathrm{b} 7 \mathrm{X} 7+\mathrm{b} 8 \mathrm{X} 8$

Berdasarkan penjabaran di atas menunjukkan bahwa, variabel independen yang dianalisis yaitu variabel $\left(\mathrm{X}_{1}, \mathrm{X}_{2}, \mathrm{X}_{3}, \mathrm{X}_{4}, \mathrm{X}_{5}, \mathrm{X}_{6}, \mathrm{X}_{7}, \mathrm{X}_{8}\right)$ memberikan pengaruh positif terhadap variabel dependen $(\mathrm{Y})$, yaitu kepuasan konsumen menggunakan sepatu futsal merek Specs di Kota Palu. Untuk lebih jelasnya penjelasan bentuk persamaan tersebut dapat dilihat berikut ini:

1. Nilai konstanta sebesar 0.578 , artinya jika variabel kualitas produk yang terdiri dari delapan dimensi bernilai 0, maka variabel dependen kepuasan konsumen menggunakan sepatu futsal merek Specs di Kota Palu nilainya sebesar 0.578.

2. Koefisien regresi dimensi bentuk $\left(\mathrm{X}_{1}\right)$ sebesar 0.396, artinya jika bentuk naik satu satuan, maka kepuasan konsumen menggunakan sepatu futsal merek Specs di Kota Palu naik sebesar 0.396.

1. Koefisien regresi dimensi fitur $\left(\mathrm{X}_{2}\right)$ sebesar 0.046, artinya jika fitur naik satu satuan, maka kepuasan konsumen menggunakan sepatu futsal merek Specs di Kota Palu naik sebesar 0.046.

2. Koefisien regresi dimensi kinerja $\left(\mathrm{X}_{3}\right)$ sebesar 0.185 , artinya jika kinerja naik satu satuan, maka kepuasan konsumen menggunakan sepatu futsal merek Specs di Kota Palu naik sebesar 0.185.

3. Koefisien regresi dimensi kesesuaian $\left(\mathrm{X}_{4}\right)$ sebesar 0.017 , artinya jika kesesuaian naik satu satuan, maka kepuasan konsumen menggunakan sepatu futsal merek Specs di Kota Palu naik sebesar 0.017 . 
Vol. 6, No.3, September 2020, 195-203

4. Koefisien regresi dimensi ketahanan $\left(\mathrm{X}_{5}\right)$ sebesar 0.138 , artinya jika ketahanan naik satu satuan, maka kepuasan konsumen menggunakan sepatu futsal merek Specs di Kota Palu naik sebesar 0.138 .

5. Koefisien regresi dimensi kehandalan $\left(\mathrm{X}_{6}\right)$ sebesar 0.066, artinya jika kehandalan naik satu satuan, maka kepuasan konsumen menggunakan sepatu futsal merek Specs di Kota Palu naik sebesar 0.066 .

6. Koefisien regresi dimensi kemudahan perbaikan $\left(\mathrm{X}_{7}\right)$ sebesar 0.052 , artinya jika kemudahan perbaikan naik satu satuan, maka kepuasan konsumen menggunakan sepatu futsal merek Specs di Kota Palu naik sebesar 0.052 .

7. Koefisien regresi dimensi gaya $\left(\mathrm{X}_{8}\right)$ sebesar 0.221 , artinya jika gaya naik satu satuan, maka kepuasan konsumen menggunakan sepatu futsal merek Specs di Kota Palu naik sebesar 0.221 .

mengetahui pengaruh signifikan secara parsial maupun simultan dari variabel independen kualitas produk yang terdiri bentuk, fitur, kinerja, kesesuaian, ketahanan, kehandalan, kemudahan perbaikan, gaya terhadap kepuasan konsumen menggunakan beberapa uji statistik seperti uji F dan uji t.

\section{a. Hasil Pengujian Hipotesis Koefisien Determinasi Ganda (Uji F)}

Berdasarkan hasil uji regresi diperoleh nilai sig F $0.000<\alpha=0,05$, dengan demikian bisa dapat disimpulkan bahwanya kedelapan variabel bebas yang diteliti, secara bersama atau serempak memberikan pengaruh signifikan terhadap variabel kepuasan konsumen menggunakan sepatu futsal merek Specs di Kota Palu, sebesar 56,2\%, maka hipotesis penelitian ini diterima.

\section{b. Hasil Pengujian Hipotesis Koefisien Determinasi Parsial (Uji t)}

Berdasarkan hasil pengujian yang diperoleh dalam penelitian ini dapat dijelaskan hasil uji t dari variabel independen adalah sebagai berikut:

\section{Pengaruh Variabel Bentuk (X1)}

Hasil yang diperoleh pada penelitian ini besar nilai sig t $0,016<\alpha=0,05$, Dengan demikian bahwa secara parsial variabel produk berpengaruh signifikan terhadap kepuasan konsumen menggunakan sepatu futsal merek Specs di Kota Palu, adapun besar pengaruh dari variabel ini adalah 0,396 atau $39,6 \%$, maka hipotesis penelitian ini diterima.

2. Pengaruh Variabel Fitur (X2)

Hasil diperoleh dari penelitian ini besar nilai sig t $0,046<\alpha=0,05$, Dengan demikian bahwa secara parsial variabel produk berpengaruh signifikan terhadap kepuasan konsumen menggunakan sepatu futsal merek Specs di Kota Palu, adapun besar pengaruh dari variabel ini adalah 0,046 atau 4,6\%, maka hipotesis penelitian ini diterima.

3. Pengaruh Variabel Kinerja (X3)

Hasil diperoleh dari penelitian ini besar nilai sig t $0,007<\alpha=0,05$, Dengan demikian bahwa secara parsial variabel produk berpengaruh signifikan terhadap kepuasan konsumen menggunakan sepatu futsal merek Specs di Kota Palu, adapun besar pengaruh dari variabel ini adalah 0,185 atau 18,5\%, maka hipotesis penelitian ini diterima.

4. Pengaruh Variabel Kesesuaian (X4)

Hasil diperoleh dari penelitian ini besar nilai sig t $0,000<\alpha=0,05$, Dengan demikian bahwa secara parsial variabel produk berpengaruh signifikan terhadap kepuasan konsumen menggunakan sepatu futsal merek Specs di Kota Palu, adapun besar pengaruh dari variabel ini adalah 0,017 atau 1,7\%, maka hipotesis penelitian ini diterima.

5. Pengaruh Variabel Ketahanan (X5).

Hasil diperoleh dari penelitian ini besar nilai sig t $0,034<\alpha=0,05$, Dengan demikian bahwa secara parsial variabel produk berpengaruh signifikan terhadap kepuasan konsumen menggunakan sepatu futsal merek Specs di Kota Palu, adapun besar pengaruh dari variabel ini adalah 0,138 atau 13,8\%. 
6. Pengaruh Variabel Kehandalan (X6)

Hasil diperoleh dari penelitian ini besar nilai sig t $0,003<\alpha=0,05$, Dengan demikian bahwa secara parsial variabel produk berpengaruh signifikan terhadap kepuasan konsumen menggunakan sepatu futsal merek Specs di Kota Palu, adapun besar pengaruh dari variabel ini adalah 0,066 atau 6,6\% maka hipotesis penelitian ini diterima.

7. Pengaruh Variabel Kemudahan (X7)

Hasil diperoleh dari penelitian ini besar nilai sig t $0,004<\alpha=0,05$, Dengan demikian bahwa secara parsial variabel produk berpengaruh signifikan terhadap kepuasan konsumen menggunakan sepatu futsal merek Specs di Kota Palu, adapun besar pengaruh dari variabel ini adalah 0,057 atau 5,2\% maka hipotesis penelitian ini diterima.

8. Pengaruh Variabel Gaya (X8)

Hasil diperoleh dari penelitian ini besar nilai sig t $0,008<\alpha=0,05$, Dengan demikian bahwa secara parsial variabel produk berpengaruh signifikan terhadap kepuasan konsumen menggunakan sepatu futsal merek Specs di Kota Palu, adapun besar pengaruh dari variabel ini adalah 0,221 atau 22,1\% maka hipotesis penelitian ini diterima.

\section{KESIMPULAN DAN SARAN}

\section{Kesimpulan}

Berdasarkan hasil dan pembahasan penelitian maka berikut beberapa kesimpulan yang menyangkut penelitian ini dengan judul "Pengaruh Kualitas Produk Terhadap Kepuasan Konsumen Menggunakan Sepatu Futsal Merek Specs di Kota Palu", adalah sebagai berikut:

1. Kualitas produk yang terdiri dari bentuk, fitur, kinerja, kesesuaian, ketahanan, kehandalan, kemudahan perbaikan, dan gaya secara bersamaan berpengaruh signifikan terhadap Kepuasan Konsumen Menggunakan Sepatu Futsal Merek Specs di Kota Palu.

2. Bentuk berpengaruh signifikan terhadap Kepuasan Konsumen Menggunakan Sepatu Futsal Merek Specs di Kota Palu.

3. Fitur berpengaruh signifikan terhadap Kepuasan Konsumen Menggunakan Sepatu Futsal Merek Specs di Kota Palu.

4. Kinerja berpengaruh signifikan terhadap Kepuasan Konsumen Menggunakan Sepatu Futsal Merek Specs di Kota Palu.

5. Kesesuaian berpengaruh signifikan terhadap Kepuasan Konsumen Menggunakan Sepatu Futsal Merek Specs di Kota Palu.

6. Ketahanan berpengaruh signifikan terhadap Kepuasan Konsumen Menggunakan Sepatu Futsal Merek Specs di Kota Palu.

7. Kehandalan berpengaruh signifikan terhadap Kepuasan Konsumen Menggunakan Sepatu Futsal Merek Specs di Kota Palu.

8. Kemudahan perbaikan berpengaruh signifikan terhadap Kepuasan Konsumen Menggunakan Sepatu Futsal Merek Specs di Kota Palu.

9. Gaya berpengaruh signifikan terhadap Kepuasan Konsumen Menggunakan Sepatu Futsal Merek Specs di Kota Palu.

\section{Saran}

Adapun saran-saran berdasarkan kesimpulan di atas ataupun saran-saran lainnya yang dapat penulis berikan adalah:

1. Variabel kesesuaian (X4), variabel paling berpengaruh terhadap kepuasan konsumen, bahwa indikator kesesuaian yang paling berpengaruh ialah penampilan. Dan sebaiknya oihak Specs mempertahankan penampilan yang sesuai dengan spesifikasi yang telah dijanjikan. 
Vol. 6, No.3, September 2020, 195-203

2. Variabel fitur (X2), variabel paling berpengaruh rendah, di sarankan dari pihak Specs lebih memperhatikan dan meningkatkan seluruh indikator pada variabel fitur.

3. Bagi penelitian selanjutnya, diharapkan bisa mencari, menambahkan, bahkan mengkombinasikan variabel pembentuk kepuasan konsumen menggunakan sepatu futsal merek Specs, agar hasil penelitiannya memberikan kontirbusi yang lebih bermakna pada pihak yang berkepentingan.

\section{REFRENSI}

Abdullah, Thamrin dan Francis, Tantri, 2012. Manajemen Pemasaran. Jakarta: Rajawali Pers

Ghozali, Imam. 2005, Uji Normalitas Regresi Dengan SPSS. Semarang: Universitas Ponegoro.

Kotler, Philip and Keller Lane Kevin, 2016. Marketing Management. Fifteennth Global Edition. Perason

Education: England.

Sugiyono, 2013, Metode Penelitian Bisnis (Pendekatan Kuantitatif, Kualitatif, dan R\&D). Bandung: Alfabeta.

Sugiyono, 2016. Metode Penelitian Manajemen. Cetakan Kelima, Bandung: Alfabeta. 